\title{
Penggunaan Metode Tanya Jawab Dalam Pembelajaran Mata Pelajaran Pendidikan Kewarganegaraan Di Sma Dharmawirawan Pepabri Makassar
}

\author{
Muhammad Asriadi ${ }^{1}$, Masni $^{2}$ \\ ${ }^{1}$ Pendidikan Teknik Informatika dan Komputer, Fakultas Teknik, Universitas Negeri Makassar, \\ ${ }^{2}$ Pendidikan Pancasila dan Kewarganegaraan, Fakultas Keguruan dan Ilmu Pendidikan, Universitas Bosowa \\ Email: muhasriadiazis@gmail.com, masni@universitasbosowa.ac.id
}

\begin{abstract}
The Use of the Question-and-Answer Method in Learning Citizenship Education Subjects at Dharmawirawan Pepabri High School Makassar. This research was conducted at Dharmawirawan Pepabri High School Makassar. The purpose of this research is to (1) determine the application of the question and answer method by the subject teachers of Citizenship Education at Dharmawirawan Pepabri High School Makassar, (2) provide an overview of knowledge about teacher and student perceptions of the use of the question and answer method in the learning process at Citizenship Education subject at Dharmawirawan Pepabri High School Makassar, (3) to find out how the obstacles a teacher faces in applying the question and answer method at Dharmawirawan Pepabri High School Makassar. This study uses a qualitative descriptive approach, with data collection carried out through interview and documentation techniques. The sample in this study were 2 class XI teachers. The results showed that: (1) The application of the question-and-answer method in the learning process of civic education at the Dharmawirawan Pepabri High School Makassar was considered to be running well. This is evidenced by the results of interviews conducted with Citizenship Education teachers who show that the application of the question and answer method in the learning process is to facilitate interaction between teachers and students so that learning activities will be more effective and efficient.(2) The consideration of a teacher choosing the question and answer method at Dharmawirawan Pepabri High School Makassar, to apply the question and answer method, which is to give effect to students to always be ready to master the subject matter before starting the teaching and learning process at school so that students will always focus on the material provided. (3) The obstacles faced by a teacher in applying the question-and-answer method at the Dharmawirawan Pepabri Makassar High School are divided into (a) the student factor (b) the duration factor, (c) the facility factor.
\end{abstract}

Keywords: Method, Questions and Answers, Learning

\begin{abstract}
Abstrak
Penelitian ini dilakukan pada Sekolah Menengah Atas Dharmawirawan Pepabri Makassar. Tujuan dari pelaksanaan penelitian ini untuk (1) mengetahui pengaplikaisan dari metode tanya jawab oleh guru mata pelajaran PKn di SMA Dharmawirawan Pepabri Makassar, (2) memberi gambaran pengetahuan tentang persepsi guru dan peserta didik terhadap penerapan metode tanya jawab dalam proses pembelajaran pada mata pelajaran PKn di SMA Dharmawirawan Pepabri Makassar, (3) untuk mengetahui bagaimana kendala-kendala seorang guru dalam mengaplikasikan metode tanya jawab di SMA Dharmawirawan Pepabri Makassar. Pendekatan dan penyajian data penelitian dilakukan melalui deskriptif kualitatif, dengan proses pengambilan data dilaksanakan dengan teknik wawancara dan dokumentasi. Sampel yang digunakan berjumlah 2 orang yang terdiri dari guru kelas XI dan XII. Dari temuan riset menunjukkan bahwa: (1) implementasi metode tanya jawab dalam kegiatan pembelajaran pendidikan kewarganegaraan di SMA Dharmawirawan Pepabri Makassar dinilai berjalan dengan baik. Fakta tersebut terbukti melalui temuan dokumentasi dan hasil wawancara yang dilakukan dengan guru PKn menunjukkan penerapan metode tanya jawab pada kegiatan belajar mengajar bertujuan untuk mempermudah komunikasi antara guru dan peserta didik sehingga kegiatan pembelajaran lebih efektif dan efisien. (2) Pertimbangan seorang guru memilih metode tanya jawab di SMA Dharmawirawan Pepabri Makassar, untuk menerapkan metode tanya jawab yaitu memberikan efek kepada peserta didik untuk mempersiapkan diri sebelum memulai proses belajar mengajar di sekolah sehingga peserta didik akan selalu fokus terhadap materi yang diberikan. (3) Kendala-kendala yang dihadapi seorang guru dalam menerapkan metode tanya jawab di SMA Dharmawirawan Pepabri Makassar yang dibagi atas (a) Faktor Peserta didik (b) Faktor Durasi, (c) Faktor Fasilitas.
\end{abstract}

Kata kunci: Metode, Tanya Jawab, Pembelajaran

\section{PENDAHULUAN}

Berbanding lurus dengan amanat Pancasila dan Undang-undang Dasar 1945 tentang tujuan pelaksanaan pendidikan yakni mencerdaskan kehidupan bangsa yang kemudian di terjemahkan kedalam Undang-undang Nomor 20 Tahun 2003 tentang Sistem Pendidikan Nasional dalam meningkatkan pembelajaran khususnya di rana pendidikan untuk mencapai peningkatan kualitas manusia, perlu di rancang secara sistematis proses pembelajaran yang dilaksanakan pada setiap lembaga pendidikan yang ada di tanah air.

Keberadaan pendidikan dewasa ini semakin dirasakan pentingnya karena itu perlu diupayakan 
dan dilaksanakan secara terus menerus dan berkesinambungan, baik melalui pelaksanaan pendidikan formal maupun non formal. Penyelenggaraan kedua sistem pendidikan tersebut bertujuan membekali murid dengan sejumlah pengetahuan dan keterampilan yang kelak akan berguna bagi kehidupannya, baik sebagai pribadi maupun sebagai makluk sosial. Menurut Buchori dalam Asriadi (2020: 13), esensi pendidikan yang tepat yakni bukan hanya membekali Peserta didik untuk menduduki suatu profesi dan jabatan saja, melainkan untuk menganalisis solusi yang dapat digunakan dalam menyelesaikan masalah-masalah yang dihadapi dalam kehidupan sehari-hari.

Didalam upaya membangun bangsa melalui dimensi pendidikan, peranan central pendidikan formal disamping pendidikan lain pada umumnya amatlah menentukan. Tujuan pelaksanaannya didasarkan pada pengembangan kualitas dan kuantitas sumber daya manusia Indonesia, sebagai mana dijelaskan pada Undang-Undang Nomor 20 Tahun 2003 tentang Sistem pendidikan nasional Pasal 3 yaitu: "Pendidikan nasional bertanggung jawab terhadap pengembangan kemampuan dan proses pembentukan watak serta peradaban bangsa yang bermartabat dalam rangka mencerdaskan kehidupan bangsa, bertujuan untuk berkembangnya potensi peserta didik agar menjadi manusia yang beriman dan bertaqwa kepada Tuhan Yang Maha Esa, berakhlak mulia, sehat, berilmu, cakap, kreatif, mandiri dan menjadi warga negara yang demokratis serta bertanggung jawab."

Pada undang-undang tersebut juga dijelaskan bahwa pendidikan merupakan upaya yang dijalankan secara terstruktur dalam membuat suasana atau kondisi belajar dan proses pembelajaran yang Baik agar peserta didik dapat berpartisipasi dalam upaya meningkatkan potensinya untuk memiliki kemampuan pengendalian diri, kecerdasan, kepribadian, akhlak mulia, serta keterampilan yang dibutuhkan olehnnya, struktur masyarakat, kehidupan bangsa dan negara. Pada esensinya, bahwa idealnya pendidikan dapat melahirkan manusia-manusia yang memiliki kecerdasan yang mampu menajdi cerminan sebagai bangsa yang cerdas pula. Sistem pendidikan saat ini bertujuan untuk pembangunan dan pengembangan potensi dan karakter yang dimiliki oleh warga negara, dengan kata lain pelaksanaan pendidikan merupakan kegiatan menciptakan manusia-manusia yang cerdas, memiliki pengetahuan dalam mengatasi masalah hidup, serta membentuk manusia yang kreatif dan inovatif.

Menurut Masni (2021: 20) diantara unsur penting dalam pendidikan yakni pada satuan pendidikan diwakilkan oleh guru sekaligus garda terdepan dalam pelaksanaan kegiatan pendidikan yang memastikan kualitas dan mutu peserta didik tercapai sesuai dengan yang diharapkan. Sejalan dengan hal tersebut, Sukriyatun (2016 : 3) menjelaskan Bahwa keberhasilan proses pembelajaran di satuan pendidikan berada di pundak para pendidik. Pendidik dalam hal ini guru dituntut untuk merencanakan proses dalam kegiatan pembelajaran dengan baik, agar unsur-unsur yang dibutuhkan dalam pembelajaran dapat berkolaborasi antar sesama komponen sehingga mudah dalam mewujudkan tujuan yang diharapkan. Didalam pembelajaran PKn, Ardianta (2014:191) berdasarkan hasil penelitian yang iya lakukan bahwa guru menginterpretasikan kegiatan pembelajaran PKn berorientasi pada output bukan pada proses yang dilalui, sehingga guru mengarahkan pada hasil kegiatan dan mengabaikan proses yang dilakuka pembelajaran.

Dari pihak guru yang diharapkan mampu memberikan pengaruh positif dan dorongan dalam mengembangkan kemampuan yang dimiliki oleh peserta didik. Pada sistem pendidikan sekolah pengaruh itu diberikan melalui serangkaian kegiatan yang disebut proses belajar mengajar (PBM).

Dalam mengajarkan mata pelajaran PKn guru dituntut memiliki kemampuan menarik perhatian serta mendorong minat murid untuk belajar. Olehnya itu guru bertanggungjawab dalam merencanakan pelajaran dengan baik sehingga substansi dari topik yang dipaparkan dapat dimengerti dengan baik oleh seluruh peserta didik di bangku SMA. Menurut Inah (2015 : 152) kegiatan pembelajaran dapat dikatakan berhasil, apabila informasi dan interaksi antara guru dengan peserta didik terjalin dan berlangsung secara berkesinambungan. Guru mampu mempersiapkan model-model yang sesuai dengan tujuan pembelajaran sehingga peserta didik dapat belajar secara optimal.

Untuk itu kehadiran penerapan metode tanya jawab sangat penting sesuai fungsi metode tanya jawab yaitu membantu peserta didik dalam mengasah daya ingat dan mengmbangkan daya pikir serta mampu mengembalikan fokus peserta didik dalam pembelajaran. tujuannya yakni dengan penggunaan metode tanya jawab pembelajaran peserta didik dapat berpartisipasi aktif dalam menerima materi pembelajaran sehingga tujuan pelaksanaan pembelajaran dapat dicapai dengan 
cepat dan tepat.

Kemampuan seorang guru dalam mengelola kelas melalui penggunaan metodemetode yang tepat sangat dibutuhkan demi memudahkan peserta didik dalam menyerap materi yang diberikan. Setiap metode yang diterapkan dalam proses pembelajaran memiliki keunggulan dan kelemahannya nya tersendiri, sehingga guru perlu melakukan analisis mendalam terhadap metode yang akan digunakan di dalam kelas

Beberapa indikator yang harus dipertimbangkan dalam menentukan metode yang akan dipergunakan pada kegiatan pembelajaran yakni: 1). Hasil yang diharapkan dari proses pembelajaran; 2). kompetensi guru dalam menerjemahkan materi serta menganalisis terkait metode yang tepat digunakan untuk materi tersebut; 3). Tingkatan berpikir; 4) Jumlah peserta didik yang belajar; 5) Situasi atau kondisi saat belajar; 6) Fasilitas yang dimiliki, dan 7). Evaluasi yang dipakai.

Tendensi dari metode tanya jawab yaitu menekankan pada proses interaksi dalam bentuk pengajuan pertanyaan kepada peserta didik untuk mendapatkan jawaban baik (respon) mengenai suatu masalah. Metode tanya jawab merupakan siasat guru dalam menyampaikan materi berupa pertanyaan yang ditujukan kepada peserta didik atau sebaliknya (Darmadi:2017). Dalam kegiatan pembelajaran, proses interaksi dalam bentuk tanya jawab merupakan sebuah kebutuhan, oleh karena pengajuan pertanyaan dengan sistematika yang tepat akan memberikan: 1). memupuk keterlibatan peserta didik dalam proses ; 2). Memberi stimulasi terhdap peningkatan motivasi belajar peserta didik; 3). meningkatkan daya pikir kritis peserta didik; 4). Meningkatkan daya ingat peserta didik; dan 5). Mengembalikan Fokus Peserta didik terhadap materi pembelajaran. Senanda dengan hal diatas, Mahdalena (2014:12) mengemukakan tentang penerapan teknik tanya jawab dapat menjadi penyelesaian masalah yang dialami guru dalam mengalihkan metode pembelajaran yang biasa digunakan secara umum menjadi metode pembelajaran inovatif responsif dan konstruktif sehingga dapat memotivasi peserta didik belajar dalam suasana yang Baik yang orientasinya terhadap peningkatan hasil belajar peserta didik.

Dengan penerapan metode tanya jawab ini, diharapkan dapat membangun kondisi belajar yang kondusif dan ideal serta membangkitkan minat peserta didik dalam menerima pelajaran. Selain itu, penggunaan metode ini diperlukan untuk memberi stimulus kepada peserta didik agar menjaga fokus pada topik pembahasan dan merekonstruksi kegiatan belajar peserta didik dalam menanggapi pertanyaan dengan penuh pertimbangan dan analisis yang tepat. Metode ini juga menurut Sitohang (2018:686) mewujudkan komunikasi yang baik antara guru dengan peserta didik dan antara peserta didik dengan peserta didik. penerapan teknik tanya jawab ini mampu menciptakan pola interaksi yang interaktif sehingga iklim belajar pada proses pembelajaran menjadi lebih hidup dan aktif.

Tujuan lain dalam penerapan metode tanya jawab ini yakni, agar peserta didik mampu memahami atau menafsirkan kembali mengenai poin-poin penting dari materi yang diberikan, baik dengan mendengar ataupun dengan proses literasi, agar peserta didik memiliki penguasaan terhadap materi yangtelah diberikan. Metode ini dapat menolong peserta didik untuk semakin mengembangkan kemampuan berpikir kreatif dan kritis seperti menganalisis, mensintesis dan mengevaluasi (Lufri et al. 2020). Selain itu, dengan metode tanya jawab diharapkan pula peserta didik mahir dalam mengaplikasikan metode berpikir kritis baik dalam proses menemukan solusi terahdap suatu permasalahan ataupun proses berpikir yang tidak sistematis sehingga menyulitkan peserta didik dalam mengidentifikasi masalah untuk dipecahkan.

\section{METODE PENELITIAN}

Penelitian ini mengkaji variabel "Penerapan metode tanya jawab dalam pembelajaran PKn ", sehingga merupakan variabel tunggal. Artinya penelitian ini tidak mengkaji variabel lain tetapi bermaksud mendeskripsikankan tentang Penerapan Metode tanya jawab guru guna meningkatkan mutu pendidikan di Indonesia.

Pendekatan dan penyajian data penelitian dilakukan melalui analisis deskriptif kualitatif. Desain ini menurut Arikunto (2010: 126) artinya peneliti mengilustrasikan atau memaparkan bentuk penerpan metode tanya jawab pada kegiatan pembelajaran peserta didik mata pelajaran PKn di SMA Dharmawirawan Pepabri Makassar.

Proses pengambilan data dilaksanakan dengan teknik: a) Wawancara (Interview) yaitu proses yang dipergunakan untuk menghimpun data atau informasi penelitian dengan jalan melakukan interaksi berupa pengajuan pertanyaan secara lisan. Wawancara yang dilakukan berfokus kepada Guru mata pelajaran PKn. b). Dokumentasi (Pengarsipan) menggambarkan proses perekaman atau pengarsipan berbagai dokumen yang terkait dengan ketercapaian tujuan dari riset ini (Sugiyono, 2013:205). 
HASIL DAN PEMBAHASAN

Penerapan Metode Tanya Jawab dalam Kegatan Pembelajaran Mata Pelajaran PKn di SMA Dharmawirawan Pepabri Makassar

Untuk dapat mengetahui akan pentingnya penerapan metode tanya jawab Secara detail dalam mata pelajaran PKn yang diterapkan di SMA Dharmawirawan Pepabri Makassar,

Berdasarkan hasil wawancara dengan Ibu Mulyana pada hari Senin tanggal 16 Maret 2021 menyampaikan bahwa:

" Pembelajaran PKn merupakan salah satu dari mata pelajaran yang wajib bagi seluruh peserta didik dalam setiap kelas yang ada pada setiap jenjang pendidikan, mata pelajaran pendidikan kewarganegaraan ini bertujuan untuk meningkatkan kompetensi dan mengembangkan ketrampilan memahami, menafsirkan, menyajikan kaidah dalam nilai-nilai Pancasila sebagai indikator pergaulan di dalam masyarakat, berbangsa dan bernegara agar dapat menjelma sebagai individu yang tutur kata dan tindakannya Penuh dengan santun dan bertanggung jawab. Maka dari itu keberhasilan pembelajaran pendidikan kewarganegaraan ditentukan oleh adanya penggunaan media pengajaran yang dipilih guru untuk menyampaikan materi pelajarannya kepada peserta didik, hal ini berarti bahwa dengan pemilihan metode tanya jawab sebagai metode dalam menyampaikan materi kepada subyek didik (peserta didik) akan membuat pelajaran menjadi lebih berhasil, sekaligus mendorong peserta didik untuk memberikan respon terhadap materi yan disampaikan guru"

Pendapat yang tidak berbeda juga diungkapkan oleh Ibu Muriani Muin di hari rabu tanggal 18 Maret 2021 guru di SMA Dharmawirawan Pepabri Makassar

"Peranan metode tanya jawab dalam proses pembelajaran sangat membantu guru dalam melaksanakan tugasnya sebab guru bukan hanya sebagai pembawa materi (mengajar) saja melainkan masih banyak tugas lain yang harus diperhatikan, misalnya guru sebagai penasehat (BK), dan wali kelas dalam arti sangat membutuhkan perhatian dengan penerapan metode tersebut. Dengan menerapkan metode tanya jawab ini guru bukan lagi sebagai sumber utama dalam menyampaikan materi pembelajaran, tetapi guru dapat memanfaatkan metode tanya jawab agar lebih efektif dan juga efisien. Sehingga, fungsi guru di dalam kelas sebagai pengarah atau mengutamakan fungsi manejerial dalam kelas. Dan fungsi utama dalam memanejerial pembelajaran adalah membuat iklim belajar yang menyenangkan, tertib dan aman agar peserta didik dapat belajar dengan baik dapat

\section{berkonsentrasi"}

Oleh karena itu secara umum manfaat dari penerapan metode tanya jawab pada kegiatan pembelajaran yaitu dengan membanngun interaksi yang baik antara guru dan peserta didik akan menciptakan iklim dan suasana yang nyaman sehingga tujuan pelaksanaan pembelajaran dapat dicapai menggunakan metode tersebut dengan efektif dan efisien.

Oleh sebab itu guru harusmampu memanfaatkan metode tanya jawab Baik dalam kegiatan pembelajaran maupun pelaksanaan fungsinya sebagai guru wali dikelas sehingga tercipta iklim belajar yang Baik dan meningkatkan pencapaian tujuan pembelajaran.

Pertimbangan Guru Memilih Menggunakan Metode Tanya Jawab dalam Pembelajaran Mata Pelajaran PKn di SMA Dharmawirawan Pepabri Makassar

Pertimbangan yang di maksud dalam hal ini adalah tanggapan atau penilaian guru terhadap penggunaan metode tanya jawab sebagai metode dalam penyampaian materi pelajaran PKn kepada peserta didik di SMA Dharmawirawan Pepabri Makassar.

Dari 2 orang guru PKn di SMA Dharmawirawan Pepabri Makassar (masing-masing guru kelas $X$ ) semuanya menganggap metode ini sangat penting untuk diterapkan pada saat proses menyampaikan materi di kelas pada mata pelajaran PKn kepada peserta didik, tentu saja harus disertakan dengan topik atau pokok bahasan dan kesiapan peserta didik dan guru sebelum menggunakan metode tersebut.

Dari hasil wawancara peneliti dengan Ibu Mulyana pada hari Senin Tanggal 16 Maret 2021, mengatakan bahwa : "Penerapan metode tanya jawab sangat perlu untuk penyampaian tujuan pembelajaran kepada peserta didik sebelum proses pembelajaran berlangsung, hal ini dilakukan dengan harapan agar terdapat kesiapan pada diri peserta didik menjalani untuk proses pembelajaran, setidaknya peserta didik dapat mengetahui bagaimana cara penerapan metode tanya jawab supaya peserta didik bisa mempersiapkan diri untuk menerima materi yang dibawakan oleh guru tersebut.".

Menurut pertimbangan guru yang mengajar di SMA Dharmawirawan Pepabri Makassar, keduanya berpendapat bahwa penerapan metode tanya jawab sangat bermamfaat karena mampu merekonstruksi proses belajar dengan lebih hidup serta membangkitkan minat peserta didik dalam menerima pelajaran. 
Kendala-Kendala yang Mempengaruhi

Penerapan Metode Tanya Jawab dalam

Pembelajaran Mata Pelajaran PKn di SMA Dharmawirawan Pepabri Makassar

Selama ini pengaplikasian metode yang sudah ada dipratekkan oleh guru-guru kelas dalam mengajarkan materi pelajaran masih saja mengalami kendala baik secara teknis maupun persiapan penggunaannya.

Berdasarkan hasil wawancara dengan Ibu Muriani Muin tanggal 18 Maret 2021 terdapat tiga (3) poin Penting yang dianggap menjadi tantangan dalam penerapan metode tanya jawab, yang meliputi:

1. Faktor durasi (waktu), yaitu durasi yang digunakan banyak terbuang terutama bila peserta didik tidak menunjukkan respon yang Cepat terhadap pertanyaan hingga tiga sampai emapt orang .

2. Faktor Peserta didik, yaitu persiapan diri peserta didikdalam menghadapi topik yang dibahas pada Hari tersebut, selain itu peserta didik terkadang merasa takut untuk mengajukan pertanyaan terlebih lagi bila model yang digunakan membosankan.

3. Faktor sarana, di sekolah belum tersedia sumber-sumber belajar yang memadai dalam proses pembelajaran, hal ini mengganggu kelancaran pencapaian tujuan pelaksanaan kegiatan pembelajaran yang diharapkan.

Lebih lanjut berdasarkan hasil wawancara yang dilakukan terhadap Ibu Muriani Muin tentang hal yang mesti dicermati untuk memperlancar jalannya kegiatan pembelajaran melalui metode tanya jawab agar kendala yang ditimbulkan relatif minim:

1. Berorientasi terhadap hasil, guru harus mengetahui tujuan dari penggunaan metode tersebut yang meliputi bidang yakni aspek pengetahuan, sikap dan keterampilan.

2. Kajian dan Analisis yaitu, kajian dalam menentukan penggunaan metode tanya jawab disesuaikan dengan kebutuhan materi yang bersifat konsep, nilai dan fakta agar pada prosesnya dapat berjalan dengan baik. Kajian terhadap refrensi yang akan digunakan tentu saja dirasa perlu dilakukan agar Perangkat pendukung dalam proses pembelajaran dapat digunakan secara efektif, analisis terhadap media yang cocok digunakan dalam mengantar peserta didik pada pencapaian hasil belajar yang diharapkan, serta bila pada proses pembuatan media terkendala pada persoalan dana, waktu dan sumberdaya lainnya dalam membuat media maka sedapat mungkin mencari solusi yang terbaik dan menganalisis alternatif yang dapat digunakan karena media yang Baik tidak ditentukan dengan dana yang besar, hal ini menunjukkan bahwa dalam menentukan media dalam mendukung metode agar memperhatikan beberapa faktor yaitu kemudahan dalam memperolehnya, mudah cara membuatnya dan penentuan metodenya berorientasi pada kemampuan dalam memaksimalkan pada saat penggunaanya dalam proses pembelajaran dikelas.

3. Metode tanya jawab yang dipilih haruslah terampil digunakan oleh guru karcna guru yang menggunakannya dalam proses pembelajaran seperti penggunaan OHP, computer dan slide seberapapun canggihnya jika guru tidak bisa mggunakannya tidak akan berarti apa. durasi serta instrumen asesmen haruspula dianalisis sebagai pendekatan praktis.

Sedangkan menurut Ibu Mulyana pada hari senin tanggal 16 Maret 2021 mengatakan bahwa : "Kendala yang biasa dihadapi seorang Guru Pkn termasuk saya adalah terkadang ada peserta didik yang tidak mau bicara sama sekali sekalipun kita sebagai guru memberikan arahan agar memberikan komentar sedikitpun, tetapi terkadang dia tidak merespon, inilah yang terkadang menjadi kendala terhadap kami sebagai guru, namu pada hakikatnya disinilah tantangan sebagai guru bagaimana caranya agar peserta didik berprestasi”

\section{SIMPULAN}

Dari hasil dan pembahasan terkait penerapan teknik tanya jawab pada kegiatan pembelajaran PKn di SMA Dharmawirawan Pepabri Makassar, kiranya dapat ditarik beberapa kesimpulan yang dapat dijadikan pegangan.

1. pelaksanaan metode tanya jawab pada kegaiatan pembelajaran PKn di SMA Dharmawirawan Pepabri Makassar dinilai sudah baik. Klaim tersebut berdasarkan hasil wawancara dengan guru PKn yang menunjukkan bahwa penerapan metode tanya jawab pada kegiatan pembelajaran merupakan upaya dalam membantu peserta didik dalam melatih daya pikir kritis terhadap topik masalah yang di hadapi.

2. Beberapa pertimbangan guru di SMA Dharmawirawan Pepabri Makassar untuk menerapkan metode tanya jawab yaitu metode ini sangat penting untuk diterapkan pada saat proses menyampaikan materi di kelas pada mata pelajaran PKn kepada peserta didik, tentu saja harus disertakan dengan topik atau pokok 
bahasan dan kesiapan peserta didik dan guru sebelum menggunakan metode tersebut.

3. Kendala-kendala yang dihadapi seorang guru dalam menerapkan metode tanya jawab di SMA Dharmawirawan Pepabri Makassar yang dibagi atas (a) Faktor Durasi (b) Faktor Peserta didik, (c) Faktor Sarana.

Atas dasar hasil dan pembahasan mengenai penggunaan teknik tanya jawab pada kegiatan pembelajaran PKn di SMA Dharmawirawan Pepabri Makassar, kiranya dapat diajukan beberapa saran guna peningkatan dalam penerapan metode tanya jawab ke depan.

SARAN

Saran-saran yang dianggap perlu adalah:

1. Pentingnya kreativitas guru pada proses penerapan metode tanya jawab didalam kelas, hal tersebut dimaksudkan untuk menumbuhkan konsentrasi terhadap pelajaran, mengurangi kebosanan peserta didik, dan menjadikan pelajaran PKn menarik bagi peserta didik.

2. Agar tujuan pelaksanaan pembelajaran PKn dapat berhasil, pimpinan sekolah memberi perhatian yang serius dalam penerapan metode pembelajaran yang diaplikasikan dalam setiap proses pembelajaran agar arah dan mutu yang diharapkan dapat dicapai dengan optimal.

\section{DAFTAR PUSTAKA}

Ardianta, I. W., Imran, I., \& Septiwiharti, D. (2014). Meningkatkan Hasil Belajar Siswa Pada Pembelajaran PKn Dengan Menggunakan Metode Tanya Jawab di Kelas V SDN 3 Kasimbar. Jurnal Kreatif Online, 2(3).

Arikunto, S. (2010). Metode peneltian. Jakarta: Rineka Cipta.

Asriadi, M., \& Masni, M. (2020). Kontribusi Media Pembelajaran pada Mata Pelajaran PPKn Di SMAN 1 Pangkajene Kabupaten Pangkep. Jurnal Media Elektrik, 17(3), 13-22.

Darmadi, H. 2017. Pengembangan Model Dan Metode Pembelajaran Dalam Dinamika Belajar Siswa. Yogyakarta: Deepublish.

Inah, E. N. (2015). Peran komunikasi dalam interaksi guru dan siswa. Al-TA'DIB: Jurnal Kajian Ilmu Kependidikan, 8(2), 150-167.

Lufri et al. 2020. Metodologi Pembelajaran: Strategi, Pendekatan, Model, Metode
Pembelajaran. Malang: CV IRDH.

Mahdalena, S., Uliyanti, E., \& Sabri, T. (2014). Penggunaan Metode Tanya Jawab Untuk Meningkatkan Hasil Belajar Siswa Pada Pembelajaran PKN Di Kelas V. Jurnal Pendidikan dan Pembelajaran Khatulistiwa, 3(3).

Masni, M., \& Asriadi, M. (2021). Studi Tentang

Kompetensi Sosial Guru PKn Di

Madrasah Aaliyah DDI Kanang

Kecamatan Binuang Kabupaten

Polewali Mandar. Jurnal Media Elektrik, 18(1), 20-27.

Sitohang, J. (2018). Penerapan Metode Tanya Jawab Untuk Meningkatkan Hasil Belajar Ipa Pada Siswa Sekolah Dasar. Suara Guru, 3(4), 681-688.

Sugiyono. (2013). Metode Penelitian Kombinasi (Mixed Methods), Bandung: Alfabeta.

Sukriyatun, G. (2016). "Penerapan Metode Tanya Jawab Untuk Meningkatkan Pemahaman Peserta Didik pada Mata Pelajaran IPS (Sejarah) Di Kelas 9.1 Tentang Perang Dunia II, Di SMPN 16 Kota Bogor Tahun Pelajaran 2012/2013. ISTORIA: Jurnal Pendidikan dan Sejarah, 12(1).

Undang-Undang, R. I. (2003). no. 20 tahun 2003 tentang Sistem Pendidikan Nasional. Bandung: Citra Umbara. 